\title{
EKSISTENSI KERATON DI CIREBON Kajian Persepsi Masyarakat terhadap Keraton-Keraton di Cirebon
}

\author{
Oleh Toto Sucipto \\ Balai Pelestarian Sejarah dan Nilai Tradisional Bandung \\ Jln. Cinambo No. 136 Ujungberung Bandung \\ Email: totosucipto@ymail.com
}

Naskah diterima: 30 Juni 2010

Naskah disetujui: 6 September 2010

\begin{abstract}
Abstrak
Karya tulis yang merupakan resume hasil penelitian ini mengungkapkan gambaran mendalam mengenai eksistensi keraton di tengah peradaban masa kini dengan fokus telaah pada persepsi masyarakat terhadap keraton. Penelitian berangkat dari anggapan bahwa keraton semakin menempati posisi marginal belakangan ini. Hal tersebut antara lain disebabkan oleh perubahan sikap dan pandangan masyarakat terhadap keraton akibat derasnya arus kebudayaan dunia dan lingkungan global. Keraton kini hanya dianggap sebagai pusat kebudayaan bagi masyarakat setempat, bukan lagi merupakan sebuah wilayah kekuasaan politik yang independen. Meskipun demikian, masyarakat masih mengenangnya sebagai salah satu lumbung budaya daerah yang potensial. Untuk mengupas permasalahan tersebut, penulis menggunakan metode penelitian deskriptif dengan pendekatan kualitatif. Adapun teknik pengumpulan datanya adalah studi literatur, observasi dan wawancara. Setelah dikaji, penulis mencoba merumuskan beberapa usulan kebijakan mengenai langkah-langkah revitalisasi keraton dalam mengantisipasi era globalisasi, yaitu mewujudkan dan memantapkan identitas kepribadian bangsa yang dikemas dengan model masa kini tanpa harus tercerabut dari akarnya.
\end{abstract}

Kata kunci: eksistensi keraton, lumbung budaya, revitalisasi keraton.

\begin{abstract}
The paper is a resumé of a research concerning depth description of the existence of keraton (karatuan = royal palace) in the middle of modern society focusing on the peoples's perception on keraton. Today people think keraton merely a cultural centre for local people, not as a domain of an independently political power. Changes in world culture and global environment might be responsible for this point of view.To analyse the problem the author conducted a descriptive research method with qualitative approach. Data were collected from bibliographical study, observation, dan interviews. Some suggestions are proposed, such as the policies that should be taken by keraton in anticipating globalization. Revitalization should be made possible in maintaining the recent national identity without having to abandon old traditional values.
\end{abstract}

Keywords: existence of the palace, granaries culture, revitalization palace 


\section{A. PENDAhuluan}

Keraton merupakan monumen yang dapat dianggap sebagai ensiklopedia sejarah. Monumen tersebut akan terpendam dan suatu saat nanti, mungkin tidak ada seorang pun yang mau menengok dan merawatnya apabila pihak pengelola keraton tidak mau menyiasati diri dari derasnya pengaruh kebudayaan luar yang negatif, yang menerobos dan memporak-porandakan kebudayaan lokal. Oleh karena itu, diperlukan adanya kesadaran untuk membuka kembali ensiklopedia sejarah itu, karena tanpa membukanya, sama artinya dengan membiarkan menjadi monumen bisu.

Keraton semakin menempati posisi marginal belakangan ini, yang antara lain disebabkan oleh perubahan sikap dan pandangan masyarakat terhadap keraton akibat derasnya arus kebudayaan dunia dan lingkungan global. Kita tidak mungkin dapat memungkiri, bahwasanya secara perlahan -- namun pasti -- eksistensi keraton di tengah peradaban masyarakat semakin memudar. Mungkin hanya satu-dua keraton seperti Yogyakarta dan Solo yang masih mendapat perhatian masyarakat, sementara selebihnya, terengah-engah mencari pijakan dan jatidirinya. Meskipun demikian, masyarakat masih mengenang keraton sebagai sebuah monumen sejarah kejayaan masa lalu. Istilah monumen, tidak hanya menunjuk pada seputar bangunan kuno belaka, tetapi dapat dianggap sebagai suatu bentuk monumen yang memuat berbagai peristiwa, baik politik, budaya, ekonomi, sosial, agama, maupun hukum.
Keraton yang berasal dari kata ke-ratu-an yang berarti tempat atau istana raja, pada zaman dulu merupakan pusat kehidupan, pusat pemerintahan, dan pusat kosmos. Dari keratonlah memancar sinar ketenteraman, keadilan, serta kebijakankebijakan tindakan sultan/raja/penguasa kepada seluruh penghuni negeri beserta kawulanya. Peran inilah yang membuat keraton dianggap sebagai sesuatu yang besar, agung, dan segalagalanya.

Keraton memang memiliki pesona tersendiri. Di lembaga elite inilah, para pendahulu menunjukkan wibawa dan kiprah kekuasaan politiknya. Di sisi lain, mereka juga mengembangkan kebudayaan dan mengasah kepekaan rasa seninya, sehingga mampu melahirkan berbagai karya seni dan budaya adiluhung yang bercita rasa tinggi. Budaya keraton memiliki spektrum yang luas, antara lain seni tari, kriya, musik, sastra, ukir, upacara adat, beladiri, makanan, busana, sampai ke seni menjadi pemimpin dan ilmu perang.

Jika menyimak kedalaman budaya keraton, akan nampak arti penting eksistensinya bagi pluriformitas budaya kontemporer. Meminjam istilah antropolog kenamaan Amerika Serikat, Edward T. Hall, keraton memberikan sumbangan bagi "budaya konteks tinggi" (high context culture), yaitu suatu budaya yang mencerminkan sekaligus merupakan penjelajahan dari inti isi kesadaran tertinggi manusia dalam rangka mencapai keutuhan humaniteir sepenuhnya.

Memang agak berlebihan jika keraton dipandang sebagai satu-satunya ujung tombak utama pelestarian budaya nasional karena masih banyak unsur 
lain dari para pelaku budaya yang berperan sangat penting. Tetapi paling tidak, melalui kekuatan historisnya, keraton menjadi salah satu masterpiece (karya agung) bangsa.

Sejalan dengan berlalunya waktu, ketika sistem pemerintahan telah berubah menjadi sistem republik berdasarkan Pancasila, keraton yang semula merupakan pusat pemerintahan, mengalami pergeseran peran secara drastis. Keraton kini hanya dianggap sebagai pusat kebudayaan bagi masyarakat setempat, bukan lagi merupakan sebuah wilayah kekuasaan politik yang independen. Memang demikianlah adanya, keraton hanyalah satu bagian dari republik ini yang ikut terpanggil mendarmabaktikan apa yang pantas disumbangkan dan siap meninggalkan apa yang seharusnya ditanggalkan. Keraton hanyalah setara dengan salah satu bagian masyarakat, yang bersama unsur-unsur lain mewarnai dan membentuk keniscayaan budaya. Dalam sosialisasi perannya, keraton diharapkan memiliki dinamika tersendiri yang tidak akan tercerabut dari akarnya, masyarakat.

Agaknya memang masih terlalu dini bila dikatakan keraton saat ini sudah identik dengan museum dan bangunan kuno tanpa makna. Namun bila pihak pengelola keraton dan pemerintah tidak segera mengambil langkah antisipatif, kecenderungan ke arah sana bukan satu hal yang mustahil. Bukan tidak mungkin bila generasi milenium mendatang hanya mengetahui bahwa masih ada keturunan rajaraja namun sudah tanpa ruh dan kering nilai; masih ada bangunan keraton, tetapi hanya berfungsi sebagai penjual kesenian; singgasana berdiri dengan megahnya, namun sama sekali tidak berperan apa pun dalam derap laju arus pembangunan.

Bagi kalangan keraton sendiri, tidak mudah memang untuk menancapkan kukunya -- kembali -- di tengah masyarakat. Bukan, tentu bukan dimaksudkan untuk menyesali maklumat penggabungan diri dan menyatakan tunduk dan berdiri di bawah pemerintahan negara kesatuan Republik Indonesia lebih dari setengah abad lalu, melainkan lebih pada ketidakberdayaan terhadap derasnya zaman yang relatif tidak lagi berpihak pada keraton. Rasa ikhlas dan kerelaan diri seorang raja berikut keturunannya untuk berdiri sejajar dengan masyarakat yang notabene tadinya merupakan rakyat dan kawulanya, ternyata harus dibayar mahal. Zaman telah berbicara dan menyeret bahkan melindas keraton secara alamiah melalui pergeseran waktu, bukan dengan sengaja atau tersistem rapi.

Dewasa ini, pandangan sebagian masyarakat terhadap keberadaan keraton memang relatif sinis. Sorotan utama terhadap keraton antara lain karena budaya feodal dan absolut yang melekat padanya. Padahal bangsa ini sudah sepakat bahwa demokrasi merupakan alat dan wahana untuk mewujudkan kemakmuran dan keadilan bangsa. Adat unggah-ungguh, nepotisme, perseliran, berbelit-belit dan tidak praktis yang dimiliki dan amat identik dengan keraton dinilai sebagai hal yang tidak lagi sesuai zaman dan karenanya merupakan satu kemunduran bila terus memanut keraton. Tentu sebenarnya banyak nilai positif milik keraton, seperti tatakrama, sopansantun terhadap yang lebih tua, ataupun 
kesenian yang adiluhung. Namun tampaknya itu semua terpudarkan oleh hal-hal miring keraton.

Terlepas dari anggapan bahwa keraton mempunyai "budaya miring" serta tertutup dari pengaruh luar, sudah selayaknya andil keraton yang memang bergeser dari aspek sosial politik ke aspek sosial budaya terus ditingkatkan. Pertimbangannya antara lain karena dewasa ini mungkin saja terdapat warga masyarakat yang tidak mengetahui bahwa di daerahnya terdapat atau pernah ada keraton. Kalaupun memang ada dan fisik keraton masih berdiri, siapa yang menjadi tokoh keraton tersebut nyaris kurang dikenal masyarakat. Dari kenyataan tersebut, lahir dua pendapat, keraton memang tenggelam atau menenggelamkan diri mempertahankan feodalisme sehingga tidak bersentuhan dengan masyarakat.

Salah satu fungsi terpenting dari eksistensi keraton di masa kini dan masa mendatang adalah posisinya sebagai sumber inspirasi pelestarian dan pengembangan budaya tradisional, yang pada gilirannya nanti diharapkan berkembang menjadi salah satu unsur pendukung kebudayaan nasional. Oleh karena itu dalam rangka menghadapi tantangan masa depan, khususnya peralihan dari millenium kedua ini, keraton jelas harus membuat langkah terobosan (breaktrough) berdasarkan visi yang jelas dan sistematis. Juga, diperlukan "penghidupan kembali" (revitalisasi) keraton dalam mengantisipasi era globalisasi, serta diperlukan penafsiran (hermeunetika) baru bagi sisi-sisi aura keraton dan kekeratonan. Secara filosofis, hal itu jelas terbuka lebar dan memiliki kemungkinan-kemungkinan sekaligus mengandung implikasi sosial budaya yang sifatnya strategis.

Di tengah situasi yang kondusif ini, pemerintah membebani keraton dengan tugas yang terhitung berat; menjadi pusat pelestarian dan pengembangan budaya nasional. Budaya macam apa yang dimiliki keraton sehingga dinilai mampu mengemban tugas sebagai pelestari dan pengembang? Tidakkah budaya nasional lebih layak diambil dari akar masyarakat sendiri ?

Berdasarkan uraian di atas, penelitian yang dilakukan di Cirebon Jawa Barat ini, berusaha terfokus pada permasalahan pokok : Bagaimana persepsi masyarakat Cirebon terhadap Keraton?

Secara umum, penelitian dilakukan dengan tujuan untuk mendapatkan gambaran yang mendalam mengenai eksistensi keraton di tengah peradaban masa kini dengan fokus telaah pada persepsi masyarakat terhadap keraton. Setelah dikaji, akan dicoba untuk merumuskan beberapa usulan kebijakan mengenai langkah-langkah revitalisasi keraton dalam mengantisipasi era globalisasi, yaitu mewujudkan dan memantapkan identitas kepribadian bangsa yang dikemas dengan model masa kini tanpa harus tercerabut dari akarnya.

Yang dimaksud dengan keraton dalam penelitian/penulisan ini adalah istana raja/sultan beserta kebudayaan dan para pelaku budayanya (pengelola keraton). Dengan demikian, apabila berbicara mengenai keraton, maka hal itu tidak berarti hanya terfokus pada istana/bangunannya tetapi menyangkut juga sultan, keluarga sultan, kerabat, atau para pengelola keraton beserta kegiatan-kegiatan yang dilakukannya. 
Secara khusus, pengertian keraton disesuaikan dengan konteks kalimat.

Sesuai dengan judul penelitian, dengan permasalahan seperti terurai di muka, maka ruang lingkupnya adalah eksistensi keraton di tengah peradaban masa kini. Fokus telaah akan mencakup aspek-aspek : kondisi fisik, struktur organisasi pemerintahan, dan kegiatankegiatan keraton; serta persepsi masyarakat terhadap keraton dengan aspek telaah: pengetahuan, sikap, kepercayaan, dan perilaku masyarakat dalam hubungannya dengan keratonkeraton yang ada di Cirebon (Kasepuhan, Kanoman, dan Kacirebonan).

Adapun ruang lingkup wilayahnya adalah Kota Cirebon. Lokasi ini dipilih berdasarkan anggapan bahwa sebagian besar masyarakat Cirebon masih mendukung kebudayaan keraton, baik Keraton Kasepuhan, Keraton Kanoman, maupun Keraton Kacirebonan.

Untuk mencapai sasaran dan tujuan penelitian yaitu menjawab permasalahan pokok penelitian dan mendapatkan data yang relevan serta pelaksanaan penelitian dapat terarah dan efektif, maka metode yang digunakan adalah deskriptif. Dasar dari metode deskriptif dalam penelitian ini adalah studi kasus dengan tujuan untuk mempertahankan objek penelitian sehingga data yang diperoleh menjadi utuh dan lengkap atau merupakan satu kesatuan yang terintegrasi. Adapun teknik pengumpulan datanya adalah studi literatur, observasi, dan wawancara. Data yang terkumpul kemudian dianalisis berdasarkan konsep dan teori yang digunakan serta pada akhirnya, disajikan dalam sebuah laporan secara deskriptif.

\section{B. HASIL DAN BAHASAN}

\section{Gambaran Singkat Cirebon}

Cirebon terletak di pantai utara bagian paling timur Jawa Barat, berjarak $248 \mathrm{~km}$ dari Jakarta dan 130 $\mathrm{km}$ dari Bandung. Secara astronomis terletak pada posisi $108^{\circ} 35^{\prime}$ Bujur Timur dan $9^{\circ} 30^{\prime}$ Lintang Selatan dengan ketinggian antara 0 - 5 meter di atas permukaan laut. Curah hujan ratarata $1.963 \mathrm{~mm} /$ tahun. Kelembaban udara mencapai angka tertinggi pada bulan Mei, yaitu sekitar $94 \%$. Adapun kelembaban terendah jatuh pada bulan Juni, Juli, dan Agustus, yaitu sekitar 48 $\%$. Iklimnya tropis dengan temperatur tertinggi mencapai $32,5^{\circ} \mathrm{C}$ (September - Oktober) dan terendah mencapai $24^{\circ}$ C (Juni - Juli) sehingga suhu rataratanya $27^{\circ} \mathrm{C}$.

Kota yang berpenduduk kurang lebih 450.000 jiwa ini merupakan kota transit yang menghubungkan ibukota negara dengan provinsi lainnya di Pulau Jawa. Dengan letak geografis yang strategis, maka tidak mengherankan Kota Cirebon tumbuh dan berkembang sebagai kota pelabuhan, perdagangan, industri, dan budaya pariwisata di Jawa Barat.

Dengan wilayah seluas 37.358 $\mathrm{km}^{2}$, Cirebon terkenal dengan berbagai julukan, antara lain : Kota Wali, Kota Udang, Kota Pelabuhan, Kota Niaga, Kota Transit, Kota Budaya, Kota Wisata, Kota Bersih, Kota Adipura, Kota Parasamya, dan Kota Industri Kerajinan. Disebut Kota Wali karena Cirebon pernah menjadi pusat penyebaran agama Islam yang disebarkan oleh Wali Sanga. Kota 
Udang, karena terkenal dengan hasil perikanan laut, terutama udang. Dijuluki sebagai Kota Bersih, Kota Adipura, dan Kota Parasamya, karena Cirebon berprestasi dalam berbagai bidang, terutama kebersihan dan tata kotanya.

Julukan sebagai Kota Pelabuhan disebabkan Cirebon merupakan satusatunya kota di Jawa Barat yang memiliki pelabuhan laut yang disebut Pelabuhan Tanjung Mas. Sebagian besar kapal yang berlabuh berupa kapal dengan kinerja pelayaran dalam dan luar negeri. Adanya sarana pelabuhan, melengkapi sarana dan prasarana transportasi yang sangat cocok untuk kegiatan perdagangan. Oleh karena itu Cirebon disebut juga Kota Niaga.

Disebut Kota Transit karena letak Cirebon yang dapat dianggap sebagai penghubung ibukota negara dengan provinsi lain di Jawa. Adapun julukan Kota Industri Kerajinan, didapat Cirebon karena banyaknya industri kerajinan (terutama homeindustry) yang tersebar di seluruh pelosok kota, antara lain kerajinan anyaman rotan, mainan, asesoris, sandal, batik, batu hiasan, lukisan, dan ukiran.

Sebutan Kota Budaya, diperoleh Cirebon karena masih hidup dan berkembangnya budaya leluhur dalam kehidupan sehari-hari, misalnya masih terdapatnya upacara adat dan kesenian tradisional. Upacara adat yang masih kerap dilakukan antara lain : Nadran yaitu upacara selamatan masyarakat nelayan, Kliwonan yaitu upacara ziarah yang dilaksanakan setiap Jumat Kliwon, dan Muludan atau Upacara Panjang Jimat yang dilaksanakan setiap tanggal 12 Maulud dengan mencuci dan mempergelarkan pusaka- pusaka yang pernah digunakan para pejuang Islam. Adapun kesenian khas yang masih dapat dijumpai di Cirebon antara lain Sintren, wayang kulit, Genjring Akrobat, batik, lukisan kaca, seni ukir kayu, Tayub, Jaran Lumping, Ronggeng Umbul, Ronggeng Bugis, Macapat Cirebon, Berokan, Topeng Cirebon, Tarling, Angklung Bungko, Debus, dan Genjring Sidapura.

Selain itu, julukan sebagai Kota Budaya, juga diperoleh Cirebon karena merupakan satu-satunya kota di Jawa Barat yang memiliki 3 keraton, yaitu Keraton Kasepuhan, Keraton Kanoman, dan Keraton Kacirebonan. Ketiga keraton tersebut memiliki akar kebudayaan yang sama, yaitu banyak dipengaruhi perkembangan agama Hindu dan Islam. Selain itu, warna kental bangunannya pun banyak dipengaruhi oleh budaya Cina, yang pada waktu itu (ketika keraton masih memiliki fungsi sebagai pusat pemerintahan) memiliki hubungan bilateral yang baik dengan ketiga keraton.

Dalam kaitannya dengan keraton sebagai sentra budaya, ketiga keraton yang ada di Cirebon ini dapat dikatakan sebagai gudang sejarah yang menyimpan berbagai peninggalan sejarah dan benda-benda kuno yang tak ternilai harganya. Kelompok kesenian yang hidup di lingkungan keraton, misalnya Sanggar Pakungwati, telah dikenal oleh masyarakat mancanegara. Sebagai tindak lanjut untuk menjaga kesinambungan agar budaya Cirebon tidak punah, telah pula didirikan Sekolah Menengah Kesenian Pakungwati yang dibuka pada tahun 1991/1992 dengan jurusan Seni Karawitan, Seni Tari, dan Seni Rupa. 
Beberapa objek wisata di Cirebon yang selama ini menjadi kebanggaan masyarakat antara lain tiga buah keraton, lengkap dengan museum benda-benda keraton dan pada waktu tertentu masih dilakukan upacaraupacara adat keratonan, Pedati Gede Pekalangan yang pernah digunakan sebagai alat angkut kayu untuk pembangunan Masjid Agung Sang Cipta Rasa, Masjid Agung Sang Cipta Rasa yang dibangun pada tahun 1703, Panggung Budaya Sunyaragi yaitu panggung pertunjukan dengan kapasitas 800 orang, serta Taman Sunan Kalijaga yaitu hutan tempat Sunan Kalijaga melakukan khotbah dan sekarang penuh dengan satwa kera (seperti objek wisata Sangeh di Bali).

Terdapatnya beberapa objek wisata seperti terurai di atas diiringi dengan masih hidup dan berkembangnya kebudayaan khas, membuat Cirebon kemudian dikenal sebagai Kota Wisata. Cirebon memang telah dikenal secara nasional. Gapura Taman Mini Indonesia Indah di Jakarta pun mengambil seni arsitektur Keraton Kasepuhan. Ini membuktikan bahwa nama Cirebon sudah masuk dalam catatan nasional.

Seperti telah diungkap di muka, kekhasan Cirebon dapat dilihat juga dari kulturnya. Cirebon tidak dapat dikatakan berkultur Jawa dan bukan pula Sunda, namun terletak di antara keduanya. Tidak heran apabila budaya yang muncul memiliki ciri khas tersendiri baik dari bahasa, tradisi, maupun etikanya, karena Cirebon dibentuk oleh keragaman yang merupakan perpaduan berbagai tradisi akibat pertemuan pendatang (sebagian besar pedagang) yang berasal dari selatan, timur, barat, dan yang melalui pelabuhan (utara). Bahasanya pun tidak sama dengan bahasa Jawa maupun Sunda. Kesan yang muncul ketika pertama kali berdialog dengan orang Cirebon adalah kasar. Bagi orang luar Cirebon, hal tersebut kadang-kadang ditanggapi sebagai kesan negatif. Dapat dibayangkan misalnya, apabila bertemu dengan temannya, kata-kata yang akrab dilontarkan adalah kirik yang berarti anjing. Tetapi apabila disimak lebih lanjut, "kekasaran" orang Cirebon yang blak-blakan dalam berbahasa tersebut ternyata merupakan sikap "akrab dan bersahabat" yang menerima dan menganggap orang lain (walaupun baru kenal) sebagai kerabat atau sahabat.

Istilah Cirebon menurut naskah Carita Purwaka Caruban Nagari yang disusun oleh Pangeran Arya Carbon pada tahun 1720 Masehi, berasal dari kata "Caruban", kemudian "Carbon", dan akhirnya "Cirebon". Sedangkan menurut sumber Portugis, yaitu berita dari Tome Pires, Cirebon disebut dengan "Chorobon". Menurut catatan Pires, Cirebon adalah sebuah pelabuhan yang indah dan selalu ada empat sampai lima kapal yang berlabuh di sana. Menurut sumber dari Belanda yang berkurun waktu abad ke-16 Masehi awal, Cirebon disebut sebagai "Charabaon", sedangkan dari sumber yang lebih muda disebutnya dengan "Cheribon", atau "Tjerbon" (Johan, 1995/1996 : 2).

Caruban berarti campuran, karena tempat itu (Cirebon) dahulunya didiami oleh penduduk dari berbagai bangsa, agama, bahasa, dan tulisan, serta pekerjaan yang berlainan pula. Sedangkan "Carbon" menurut para wali berarti "puser jagat", karena terletak di 
tengah-tengah Pulau Jawa. Cirebon oleh penduduk setempat disebut "Nagari Gede", kemudian menjadi "Garege", dan selanjutnya menjadi "Grage". Mungkin juga, "Grage" berasal dari "glagi", yaitu nama udang kering untuk bahan membuat terasi. Istilah Cirebon secara kiratabasa (volksetymologi) berasal dari "Ci" dan "Rebon", "Ci" (bahasa Sunda) berarti air, dan "Rebon" adalah sejenis udang kecil yang merupakan bahan untuk membuat terasi. Disebut demikian karena jika dihubungkan dengan kenyataan, Cirebon dari dahulu hingga saat ini merupakan penghasil udang dan terasi (Atja, 1972 : 1).

Menurut manuskrip Carita Purwaka Caruban Nagari, cikal bakal Cirebon adalah sebuah desa nelayan yang bernama Muarajati. Suasana desa tersebut sangat ramai karena setiap harinya didatangi nelayan dan pedagang dari berbagai daerah. Selama bertahun-tahun, desa tersebut bertambah maju dan menjadi pelabuhan yang tidak pernah sepi sehingga terkenal ke berbagai wilayah nusantara.

Ki Gedeng Alang-alang, seorang utusan dari Kerajaan Galuh (Pajajaran), diberi kepercayaan menjadi penanggung jawab keamanan dan penanganan wilayah di sekitar Pelabuhan Muarajati. Atas jasanya itu, ia kemudian dikenal sebagai Ki Kuwu Cerbon. Ia lalu memindahkan pemukiman nelayan ke daerah Lemahwungkuk.

Pada masa kejayaan kerajaan Pajajaran, Pangeran Walangsungsang (putera Prabu Siliwangi) diangkat sebagai Adipati Cirebon dengan gelar Cakrabuana. Pangeran inilah yang kemudian mendirikan keraton sebagai pusat pemerintahan di Cirebon dan mulai menyebarkan serta mengembangkan agama Islam.

Pada jaman pemerintahan Prabu Djamadjan (1350), Cirebon kedatangan saudagar-saudagar dari Negeri Arab, yaitu Syeh Datuk Kahfi, Syeh Datuk Mahayun beserta dua belas orang pengikut. Mereka menyebarkan dan menyemarakkan perkembangan agama Islam yang juga disyiarkan oleh para wali dan keturunannya.

Perkembangan agama Islam mengalami kemajuan yang pesat pada masa pemerintahan Syeh Syarif Hidayatullah (Sunan Gunung Jati) karena selain berupaya meningkatkan kesejahteraan masyarakat melalui pembangunan fisik/materi, Sultan Cirebon ini terus menerus mengembangkan dan menyiarkan agama Islam dalam pembangunan nonfisiknya. Pada masa inilah, Cirebon dapat melepaskan diri dari kekuasaan Kerajaan Sunda Pajajaran yang pada waktu itu rajanya adalah Sri Baduga Maharaja atau lebih dikenal dengan sebutan Prabu Siliwangi. Mulai saat itu, Cirebon merupakan sebuah kerajaan Islam berdaulat dan tidak lagi berada di bawah kekuasaan kerajaan manapun.

Ketika Cirebon berada di bawah pimpinan Panembahan Girilaya (1649 1667 M), wilayahnya meliputi Kuningan, Majalengka, dan Indramayu. Setelah Pangeran Girilaya meninggal dunia, Cirebon dibagi menjadi tiga bagian, yaitu Kesultanan Kasepuhan (Samsudin Martawijaya), Kesultanan Kanoman (Badrudin Kartawijaya), dan Kesultanan Kacerbonan (Pangeran Wangsakerta). Dengan dibagi menjadi tiga kesultanan berarti terdapat perubahan yang drastis dalam struktur pemerintahan. Begitu pula dalam 
wilayah kerajaan, terbagi menjadi tiga wilayah. Namun di dalam sumber sejarah lokal, tidak begitu dijelaskan daerah mana yang masuk Kesultanan Kasepuhan, Kanoman, dan Kacerbonan.

R.H. Unang Sunardjo, dalam bukunya "Meninjau Sepintas Panggung Sejarah Pemerintahan Kerajaan Cerbon (1479 - 1809)" memperkirakan bahwa untuk sementara waktu (1677 - 1678) pembagian wilayah secara definitif belum dilakukan sehingga seluruh wilayah Kerajaan Cirebon yang ditinggalkan oleh Panembahan Girilaya dikuasai bersama oleh ketiga puteranya, dengan beberapa pengecualian untuk tempat-tempat tertentu.

Pada tanggal 2 Pebruari 1809, Pemerintah Kolonial Belanda mengeluarkan peraturan khusus yang mengatur pembagian wilayah kekuasaan dan jabatan di Cirebon (Reglement of het beher can Cheribonche Landen). Menurut peraturan tersebut, wilayah Cirebon dibagi menjadi dua bagian, yaitu :

Bagian utara disebut wilayah Kesultanan Cirebon yang meliputi daerah-daerah Kuningan, Cirebon, Indramayu, dan Gebang.

Bagian selatan yang disebut tanah-tanah Priangan yang meliputi wilayah Kabupaten Limbangan, Kabupaten Sukapura, dan Kabupaten Galuh (Atja, 1989 : 35 dalam Ekadjati, 1991: 23).

Pada tanggal 13 Maret 1809, bagian utara dikepalai oleh tiga orang sultan (Sultan Kasepuhan, Sultan Kanoman, dan Sultan Kacirebonan). Wilayah kekuasaan Sultan Sepuh (Kasepuhan) adalah bagian selatan yang daerahnya meliputi Kabupaten
Kuningan dan Kabupaten Cirebon; bagian tengah adalah kekuasaan Sultan Anom (Kanoman) yang diperkirakan sama dengan daerah Kabupaten Majalengka sekarang, dan Sultan Kacirebonan menguasai wilayah Indramayu yang terletak sebelah barat Cimanuk dan Kandanghaur. Sedangkan kota Cirebon dan sekitarnya yang, terdiri dari pesawahan dibagi dua antara Sultan Sepuh dan Sultan Anom. Ketiga daerah kesultanan itu meliputi pesawahan seluas 4300 jonk (jung) dan berpenduduk 80.000 jiwa (Veth, 1878 II : 556 dalam Atja, $1988: 38$ - 39).

Pada tahun 1906, Cirebon menjadi daerah otonom dan pada tahun 1942 ditetapkan sebagai daerah karesidenan. Pada tahun 1950, melalui UU No. 16 Tahun 1950, Cirebon menjadi daerah otonom dengan nama "Kota Besar Cirebon". Perubahan status Kota Cirebon berlanjut dengan turunnya UU NO. 13 Tahun 1954, yang mengubah status daerah otonom menjadi Daerah Tingkat II Kotamadya.

\section{Persepsi Masyarakat Cirebon terhadap Keraton}

Walaupun kekuasaan dalam bidang politik berkurang, pengaruh keraton dalam tradisi dan budaya tetap kuat dan berlangsung sampai sekarang. Dalam lubuk sanubari masyarakat Indonesia, tradisi keraton tetap dihormati dan keturunan para penguasa yang umumnya masih tinggal di "bekas" pusat kerajaan atau keraton dan sekitarnya, masih tetap diagungkan. Demikian juga, di alam lingkungan dalam tembok keraton, ketaatan ritual dan upacara kerajaan masih tetap dilaksanakan untuk menghormati kebiasaan dan tata cara leluhur yang terus hidup berabad-abad lamanya. 


\begin{abstract}
Banyaknya wisatawan, baik wisman maupun wisnus yang berkunjung ke keraton, memunculkan harapan bahwa keraton belum dikesampingkan dalam khasanah kehidupan masyarakat; terlepas dari sekadar mencari alternatif hiburan, mengisi masa liburan, atau alasanalasan lain. Hanya saja patut disayangkan jika pengunjung memanfaatkan acara tersebut untuk tujuan lain. Misalnya orang yang mengambil air sumur di lingkungan keraton dengan anggapan untuk membawa berkah. Hal tersebut perlu diluruskan, agar tidak sampai timbul syirik. Demikian pula peziarah yang memohon sesuatu kepada tokoh yang dimakamkan di situ. Semua doa seharusnya dipanjatkan kepada Allah SWT, sedangkan tokoh yang sudah meninggal justru dipanjatkan doa atas segala amal kebajikan selama hidupnya.
\end{abstract}

Terlebih lagi hampir semua keraton Nusantara memiliki nuansa keIslam-an yang kental. Tentunya pemujaan terhadap pemimpin bukan bertujuan mempertahankan feodalisme, tetapi sekadar kepatuhan terhadap seorang umara dalam mengarahkan masyarakat mengarungi kehidupan. Kalaupun aspek sosial politik sudah tidak tampak -- tergantikan aspek sosial budaya -- kepemimpinan keraton dalam hal budaya agaknya masih relevan. Keraton bisa menjadi kiblat adat dan budaya, turut membantu penyebaran agama serta meluruskan mitos di masyarakat. Apalagi benda-benda yang dikeramatkan seringkali banyak dijumpai di lingkungan keraton, namun anggap saja benda tersebut bukan memiliki kekeramatan melainkan menimbulkan wibawa bagi tokoh yang saat itu menyandangnya.
Benda-benda pusaka tersebut memang bertujuan menampilkan wibawa sosok pemimpin. Semacam atribut kepangkatan saat ini. Kalaupun benda tersebut bertuah, tidak lepas dari perkenan dan kehendak Khalik yang Maha Kuasa.

Bagaimanapun, banyaknya pengunjung menyiratkan bahwa "ensiklopedia sejarah" yang disandang keraton masih diminati; walaupun tidak "diselami" tetapi setidaknya "dibaca" untuk dikenal dan mudah-mudahan tetap dikenang sebagai khasanah budaya bangsa yang berharga. Pada gilirannya kelak, masyarakat diharapkan dapat semakin memahami dengan cermat berbagai segi kekayaan budaya keraton dengan merasakan geliat keraton yang pernah (dan masih) berkiprah menjadi titik sentrum budaya adiluhung bangsa.

Menyimak masih terdapatnya pengunjung yang "menziarahi" keraton, berikut ini akan diungkapkan hasil penelitian mengenai persepsi masyarakat Cirebon terhadap keratonkeraton yang ada di Cirebon (Keraton Kasepuhan, Keraton Kanoman, Keraton Kacirebonan) yang terinci ke dalam empat pokok bahasan, yaitu pengetahuan, sikap, kepercayaan, dan perilaku masyarakat dalam hubungannya dengan kegiatan keraton.

Sebagai tujuan wisata di "kota udang", keraton-keraton yang ada Cirebon bukan hanya milik warga Cirebon, tetapi juga aset Jawa Barat, bahkan dapat dikatakan merupakan harta negara. Keraton Kasepuhan misalnya, yang dahulunya lebih dikenal dengan sebutan Keraton Pakungwati, merupakan salah satu peninggalan kerajaan di Jawa Barat yang masih ada. Keraton ini dibangun oleh Pangeran 
Cakrabuana dan kemudian dikembangkan oleh Sunan Gunung Jati, seorang umaro dan ulama besar, salah seorang dari Wali Sanga yang menyebarkan agama Islam di Tanah Jawa. Sunan Gunung Jati inilah yang berhasil membawa Kerajaan Cirebon ke puncak kejayaan.

Suasana lengang yang menyelimuti sekelilingnya ketika tidak ada kegiatan atau perayaan upacara tradisi keraton, masih menampakkan sisa-sisa kejayaan masa lalu. Bangunan kuno, besar, kokoh dan antik, seolah memberikan gambaran bahwa pendirinya memiliki kepekaan rasa seni dengan kebudayaan yang adiluhung.

Di samping tetap berupaya memelihara nilai-nilai sejarah bangunan-bangunan yang ada di kompleks Keraton Kasepuhan, sampai sekarang pihak pengelola keraton berusaha untuk konsisten dengan tetap mempertahankan tradisi, antara lain melaksanakan perayaan upacara tradisi keraton secara rutin setiap tahun walaupun dana yang diperlukan untuk membiayai perhelatan tersebut relatif besar.

Diakui oleh pihak pengelola keraton bahwa upaya pelestarian yang identik dengan perawatan selalu menjadi kendala. Oleh karena itu, tanpa mengurangi nilai yang terkandung di dalamnya, kekayaan yang dimiliki kemudian dikemas untuk dijual sebagai wahana pariwisata. Hal tersebut didasarkan atas kenyataan bahwa walaupun ketersediaan sarana pariwisata sudah relatif memadai, tetapi apabila sarana dan acaranya tidak dikemas dan ditingkatkan, maka para wisatawan belum tentu mau memperpanjang lama tinggal. Dengan cara demikian, mahalnya biaya untuk merawat keraton dan penyelenggaraan upacara tradisi keraton dapat diatasi dengan pemasukan dari pergelaran atau kunjungan wisatawan.

Perlu disadari bahwa mempertontonkan keraton tidak berarti mempertunjukkan keluarga keraton, namun menunjukkan hasil karya para pendahulu maupun hasil kreasi keturunannya yang kini masih ada. Oleh karena itu, pengemasan budaya keraton sebaiknya memperhatikan juga aspek-aspek lain yang tidak melulu berorientasi pada bisnis komersial.

Terlepas dari anggapan keraton tertutup dari pengaruh luar dan sebaliknya dalam menyebarkan aneka kekayaan budaya yang dimilikinya bagi lingkungan sekitar, salah seorang Sultan dari ketiga Sultan di Cirebon menyatakan bahwa andil keraton yang memang bergeser dari aspek sosial politik ke aspek sosial budaya, terus menerus ditingkatkan. Sebagai bukti, kunjungan wisatawan yang datang ke keraton semakin meningkat dari tahun ke tahun.

Berbagai upacara dan ritus budaya yang terkadang disertai unsur magis dan sakral menjadi sajian apik bagi wisatawan. Antusiasme pengunjung cukup menggembirakan, terlepas dari sekadar mencari alternatif hiburan, mengisi masa liburan, mengenal sejarah Cirebon, atau alasan-alasan lain. Hanya saja patut disayangkan apabila pengunjung memanfaatkan acara kunjungannya tersebut untuk tujuan yang mengkultuskan tokohtokoh keraton atau menganggap beberapa benda/bagian dari keraton dapat membawa berkah dan keselamatan. 
Hasil penelitian mengungkapkan terdapatnya beragam persepsi masyarakat mengenai keraton. Persepsi di sini didefinisikan sebagai proses kognitif (pemberian arti) yang dipergunakan seseorang untuk menafsirkan dan memahami dunia sekitarnya. Persepsi mencakup kognisi, pengetahuan, penafsiran objek, tanda dan dari sudut pengalaman yang bersangkutan (Gibson dkk., 1987).

Miftah Thoha (1983) berpendapat bahwa pada hakikatnya persepsi adalah proses kognitif yang dialami oleh setiap orang di dalam memahami informasi tentang lingkungannya, baik melalui pendengaran, penghayatan, perasaan dan penciuman. Proses kognitif tersebut dapat diartikan meliputi kegiatan mental yang sadar seperti berpikir, mengetahui, memahami, dan kegiatan persepsi mental seperti sikap, kepercayaan, dan pengharapan yang kesemuanya itu menentukan dalam perilaku manusia.

Dari beberapa pengertian seperti di atas, persepsi masyarakat dalam penulisan ini dilihat melalui pengetahuan, sikap, kepercayaan, dan perilakunya. Adapun untuk menjaring data dan informasi tentang pengetahuan responden mengenai keraton, penulis menelusurinya melalui beberapa aspek yaitu pengetahuan tentang adanya keraton di Kota Cirebon, lokasi, bangunan-bangunan, sejarah, terdapatnya sultan, sultan keturunan Sunan Gunung Jati, dan sumber informasi tentang keraton.

Hasil penelitian mengungkapkan bahwa hampir seluruh masyarakat Cirebon mengetahui di kotanya terdapat Keraton Kasepuhan, hanya beberapa orang saja yang tidak mengetahui lokasi keraton secara tepat.
Demikian juga, ketika ditanya mengenai bangunan-bangunan/bagianbagian yang terdapat di kompleks keraton, sebagian besar mengetahui letak dan nama bangunan-bangunan utama bahkan beberapa di antaranya dapat menyebutkan secara rinci dan lengkap. Mengenai sejarah keraton, sebagian besar menyatakan "tahu" walaupun hanya garis besarnya, yaitu pendirian Pedukuhan Caruban pada masa Pangeran Cakrabuana, kejayaan Kerajaan Cirebon pada masa Syarif Hidayatullah atau Sunan Gunung Jati, dan terpecahnya Kerajaan Cirebon menjadi Keraton Kasepuhan, Keraton Kanoman, dan Keraton Kacirebonan.

Ketika diajukan pertanyaan : Apakah masih terdapat sultan di ketiga keraton yang ada di Cirebon? Sebagian besar warga masyarakat menyatakan mengetahui bahkan lebih dari setengah di antaranya dengan jelas mengungkapkan bahwa sultan-sultan tersebut adalah keturunan Sunan Gunung Jati. Mereka yakin benar dengan pernyataannya itu. Adapun sumber informasi tentang Keraton Kasepuhan, mereka peroleh dari media yang bervariasi : keluarga, tetangga, media cetak lokal, media elektronik lokal, teman, dan pengajar. Patut disayangkan bahwa media masa yang diharapkan dapat menyebarluaskan informasi mengenai keraton, ternyata relatif kurang berperan. Masih sedikit sekali dijumpai adanya tayangan kegiatan-kegiatan dan informasi mengenai keraton-keraton yang ada di Cirebon pada media masa.

Secara umum dapat dikatakan bahwa asumsi yang menyatakan keraton kurang dikenal masyarakat, ternyata malah sebaliknya. Hampir seluruh masyarakat mengetahui dan 
dengan jelas dapat menunjukkan lokasi terdapatnya ketiga keraton di Kota Cirebon serta mengetahui siapa sultan yang menjadi "penguasa" keratonkeraton tersebut sekarang.

Persepsi masyarakat yang ditelusuri melalui sikap terhadap keraton, dirinci dengan paparan mengenai perlu/tidaknya keraton dirawat dan dijaga, keberadaan sultan, pelestarian budaya keraton, dan pengubahan upacara tradisi keraton agar sesuai tuntutan jaman. Hasil penelitian mengungkapkan bahwa sebagian besar warga Cirebon menginginkan keraton dan budayanya dirawat dan dijaga. Memang, terdapat beberapa warga yang meragukan apakah keraton beserta budayanya tersebut perlu dirawat atau dijaga, mengingat terdapatnya budaya "miring" keraton seperti adat unggahungguh, perseliran, nepotisme, birokrasi yang berbelit-belit, dan budaya feodal. Akan tetapi sebagian besar lainnya berkilah bahwa budaya "miring" keraton tersebut hanyalah sebagian kecil saja dibanding budaya positif yang dimiliki keraton seperti tata krama dan kesenian yang adiluhung.

Persoalan yang berkaitan dengan eksistensi keraton, antara lain terungkap dari kenyataan masih diperlukan terdapatnya seorang sultan. Selain itu, sultan juga dapat dikatakan sebagai "simbol adat dan budaya keraton" sehingga setiap kegiatan yang mempergelarkan budaya keraton, terutama upacara tradisi keraton, selalu mengharapkan adanya sultan yang bertindak selaku penanggungjawab dan pemimpin kegiatan.
Sebagian besar warga Cirebon ternyata sangat mendukung upaya pelestarian budaya keraton. Mereka mengajukan argumen bahwa budaya keraton seperti seni tari, kriya, sampai ke seni menjadi pemimpin dan ilmu perang, termasuk tata krama dan sopan santun, sangat perlu untuk dilestarikan dalam arti didokumentasikan, dikaji, dan dikembangkan karena sangat mendukung perkembangan kebudayaan nasional.

Pengertian pelestarian termasuk juga upaya mempertahankannya dari intervensi budaya luar/asing yang pada masa globalisasi ini sangat deras memutarkan jaman. Oleh karena itu, sebagian besar warga Cirebon menyatakan tidak perlu mengubah upacara-upacara tradisi keraton sesuai dengan tuntutan zaman karena apabila diubah, maka aspek "asli"nya tidak murni lagi, bahkan mungkin nilai-nilai budaya luhur yang terkandung secara simbolik pada setiap unsur upacara tradisi keraton akan kabur atau hilang.

Akan tetapi, "mempertahankan" bukan berarti menutup masuknya unsur budaya asing karena di antara unsur budaya asing tersebut terdapat juga yang positif dan dapat diserap untuk memperkaya kebudayaan keraton. Unsur budaya asing tersebut selayaknya diterima secara selektif tanpa menghilangkan jati diri. Dengan demikian, yang dimaksud "mempertahankan" di sini adalah tetap eksisnya nilai-nilai budaya keraton walaupun menyerap unsur budaya luar/asing yang dianggap lebih sesuai dengan situasi dan kondisi sekarang.

Persepsi masyarakat yang ditelusuri melalui kepercayaan terhadap keraton, mengungkapkan bahwa 
sebagian besar warga Cirebon mempercayai kebudayaan keraton bisa mendukung kebudayaan nasional. Hal tersebut dapat dimengerti mengingat budaya keraton memiliki spektrum yang luas, antara lain seni tari, seni lukis, musik, sastra, ukir, upacara adat, beladiri, makanan, busana, tatakrama, sopan santun terhadap yang lebih tua, sampai ke seni menjadi pemimpin dan ilmu perang.

Karya seni dan budaya adiluhung yang bercitarasa tinggi tersebut merupakan hasil kinerja para pendahulu (nenek moyang) yang tidak henti-hentinya mengembangkan kebudayaan dan mengasah kepekaan rasa seni. Hasil karya tersebut semakin berkembang lagi di masa kini karena generasi selanjutnya dan masa kini, selalu berupaya membina dan mengembangkan serta memperkaya nuansa seni dan budaya dengan inovasi melalui kreativitas yang tidak hentihentinya. Oleh karena itu, tidaklah berlebihan apabila sebagian besar warga menyatakan "tidak setuju" apabila terdapat pernyataan bahwa kebudayaan keraton akan hilang ditelan zaman.

Mengingat eksisnya budaya keraton dan nama Keraton Kasepuhan Keraton Kanoman - Keraton Kacirebonan masih tetap dikenal, sebagian besar warga menganggap pengelola keraton masih berperan dan menjalankan kewajibannya dalam menjaga dan merawat keraton (plus budayanya) dengan penuh tanggung jawab. Dalam hal ini, sultan sebagai pemimpin dan kepala keluarga keraton berperan sebagai pelindung, penasihat, dan pengarah langkah.

Oleh karena masih berperannya sultan dalam upaya membuat keraton tetap eksis walaupun tidak memiliki wilayah kekuasaan politik yang independen, warga Cirebon percaya bahwa Sultan memiliki ilmu yang adiluhung. Kepercayaan warga tersebut didukung oleh pernyataan beberapa informan yang menyatakan bahwa untuk dapat berperan dan setiap perkataannya didengar atau dijalankan oleh "bawahannya", maka sultan harus memiliki kemampuan memimpin dan mengerahkan "bawahan", berwibawa, adil, serta sarat dengan ilmu. Ilmu-ilmu tersebut adalah ilmu agama (Islam), ilmu fisika (syariat), dan ilmu metafisika (hakikat, tarekat, dan ma'rifat).

Kepercayaan yang tampaknya harus diluruskan karena relatif mengkultuskan tokoh atau para pendiri kerajaan beserta keturunannya, adalah timbulnya anggapan dari beberapa warga bahwa benda-benda pusaka, bagian-bagian keraton yang "asli" (belum dipugar atau direkayasa), dan beberapa peninggalan sejarah lainnya, bertuah dan dapat mendatangkan berkah. Kepercayaan warga tersebut tentu saja mengkhawatirkan karena kepercayaan seperti itu akan menjurus kepada syirik, menyekutukan Allah. Oleh karena itu, sudah selayaknyalah apabila pihak terkait, terutama pihak pengelola keraton, dapat memberi informasi yang relatif jelas dan mudah dimengerti dengan tujuan meluruskan anggapan yang menyimpang dari ajaran agama (Islam) tersebut.

Persepsi yang ditelusuri melalui perilaku masyarakat dalam hubungannya dengan keraton, ditelaah dengan mengetahui informasi mengenai kehadiran dalam upacara-upacara tradisi keraton, perilaku ketika berjumpa dengan keluarga keraton, dan 
perilaku terhadap budaya keraton. Hasil penelitian mengungkapkan terdapatnya warga yang menyatakan "selalu" dan "seringkali" menghadiri upacaraupacara tradisi keraton. Antusiasme warga untuk menyempatkan diri hadir dalam kegiatan dimaksud, terdorong oleh beragamnya tujuan, yaitu antara lain karena bernilai sakral atau sekadar alternatif hiburan.

Beberapa warga menyatakan kagum, bangga, dan sangat hormat terhadap sultan dan keluarganya karena mereka adalah keturunan Sunan Gunung Jati, seorang wali yang sangat dipuja dan cenderung dikultuskan sehubungan perannya yang besar dalam menyebarkan agama Islam serta membuat Kerajaan Cirebon berada di puncak kejayaan. Apabila berjumpa dengan keluarga keraton, beberapa warga Cirebon akan berperilaku layaknya rakyat terhadap rajanya. Terdapat juga yang berperilaku "biasa saja" dengan anggapan bahwa sultan dan keluarga keraton adalah manusia biasa tanpa kelebihan apapun. Warga lainnya bersikap realistis, berperilaku "sedikit berbeda" karena menurut mereka, bagaimanapun keluarga keraton adalah keturunan penguasa Cirebon jaman dahulu yang berperan dalam membangun dan mengembangkan Cirebon.

Adapun perilaku wargta dalam hubungannya dengan budaya keraton, baik berupa kesenian maupun tata krama dan sopan santun, sebagian besar menyatakan mendukung, berupaya melestarikan dan mengembangkannya dengan berbagai cara. Cerminan perilaku warga tampak misalnya dengan menguasai salah satu jenis kesenian, memiliki sanggar tari atau galeri, terlibat dalam pergelaran budaya keraton, dan lain-lain.

Menyimak hasil penelitian seperti terurai di muka, tampaknya kekhawatiran bahwa keraton dan budayanya yang adiluhung akan semakin pudar, tidak terbukti apabila masyarakat masih mendukung dan peduli. Walaupun keraton mengalami pergeseran peran secara drastis, yaitu bukan lagi sebuah wilayah kekuasaan politik yang independen tetapi hanya dianggap pusat kebudayaan bagi masyarakat setempat, keraton tetap memiliki dinamika tersendiri yang tidak akan tercerabut dari akarnya, masyarakat.

Hasil penelitian mengungkapkan bahwa keraton-keraton di Cirebon masih memiliki "ruh" dan tidak kering nilai, serta tetap berperan dalam derap laju arus pembangunan. Kedudukan dan sosok keraton pada saat ini dipandang masyarakat Cirebon dengan perspektif baru; suatu perspektif yang menempatkan keraton pada proporsi yang modern, tidak lagi berupa tafsiran tempo dulu yang menganggap keraton menakutkan. Keraton dianggap sebagai sumber inspirasi pelestarian dan pengembangan kebudayaan tradisional.

Pernyataan tersebut di atas mengingatkan sekaligus menyadarkan, bahwa biarpun Indonesia telah menjadi negara kesatuan yang berbentuk republik, tidak berarti keraton ditinggalkan begitu saja. Keraton tetap menjadi lumbung budaya nasional dan bersama dengan kebudayaan daerah/lokal, memperkaya perbendaharaan budaya bangsa. Keduanya saling mengisi dan memperkokoh kebudayaan nasional. 


\section{PENUTUP}

Seperti telah diungkap pada awal tulisan ini, salah satu fungsi terpenting dari eksistensi keraton di masa kini dan masa mendatang adalah posisinya sebagai sumber inspirasi pelestarian dan pengembangan budaya tradisional. Oleh karena itu dalam rangka menghadapi tantangan masa depan, keraton jelas harus membuat langkah terobosan (breaktrough) berdasarkan visi yang jelas dan sistematis. Juga, diperlukan "penghidupan kembali" (revitalisasi) keraton dalam mengantisipasi era globalisasi, diiringi penafsiran (hermeunetika) baru bagi sisi-sisi aura keraton dan kekeratonan. Secara filosofis, hal itu jelas terbuka lebar dan memiliki kemungkinankemungkinan sekaligus mengandung implikasi sosial budaya yang sifatnya strategis.

Untuk mewujudkan revitalisasi, yaitu ungkapan pembukaan ruang budaya sebagai bangsa dalam proses pengayaan nuansa keraton agar nilai keindonesiaannya semakin tampak, diperlukan konvergensi nilai-nilai budaya yang rumit. Revitalisasi ini tidak ditafsirkan dalam konteks yang sempit, dalam arti citra baru secara fisik dan manajerial semata-mata, yang hanya bertujuan pada peningkatan pendapatan daerah di sektor pariwisata. Revitalisasi seyogyanya menggapai wawasan yang lebih jauh dan lebih luas, yakni mewujudkan dan memantapkan sebuah identitas kepribadian bangsa. Dunia keraton dengan berbagai dimensinya, diupayakan dapat melebur berbagai unsur budaya masa lalu secara tuntas dengan model kemasan masa kini tanpa harus tercerabut dari akarnya.
Langkah awal revitalisasi keraton adalah memperkenalkan wajah keraton seluas-luasnya kepada masyarakat, antara lain melalui pergelaran budaya keraton, pameran benda pusaka keraton, atau melalui festival seperti Festival Keraton Nusantara. Dengan ajang seperti itulah, kesempatan terbuka lebar bagi masyarakat untuk menikmati dan mengapresiasikan suguhan acara/ kegiatan, serta meninjau dan memahami dengan cermat berbagai segi kekayaan budaya keraton. Lebih jauh, masyarakat diharapkan dapat merasakan geliat keraton yang berkiprah menjadi titik sentrum budaya adiluhung bangsa.

Masyarakat, juga diharapkan dapat memberikan apresiasi secara lebih proporsional terhadap nilai-nilai luhur dan positif yang terpancar dari lingkungan kehidupan keraton. Menyalahkan keraton terus-menerus karena ketidakmampuannya membaca zaman -- yang pada gilirannya kelak, mungkin menggilasnya -- pun tampaknya kurang relevan. Banyak determinan lain yang merupakan tantangan dan menuntut kebersamaan untuk menuntaskannya.

\section{DAFAR PUSTAKA}

Adeng dkk., 1998.

Kota Dagang Cirebon sebagai Bandar Jalur Sutera, Jakarta : Proyek IDSN.

Argadikusumah, E. Nurmas, 1998.

Baluarti Kraton Kasepuhan, Brosur dari Unit Pengelola Keraton Kasepuhan Cirebon. 
Atja, 1972.

Tjarita Purwaka Tjaruban

Nagari, Ikatan Karyawan

Museum.

1988.

Menjelang Penetapan Hari Jadi

Pemerintah Kabupaten Cirebon.

Edi S. Ekadjati, 1978.

Babad Cirebon Edisi Brandes

Tinjauan Sastra dan Sejarah,

Bandung : Fakultas Sastra

Universitas Padjadjaran.

Sejarah Perkembangan

Pemerintah Propinsi DT I Jawa

Barat, Bandung : Pemerintah

Propinsi DT I Jawa Barat. 1992.

Sejarah Cirebon Abad Ketujuh

Belas, Bandung : Kerjasama

Pemerintah DT I Propinsi Jawa

Barat dan Fakultas Sastra Unpad.

Falah, W. Anwar, 1996.

"Tinjauan Konsepsi Seni Bangunan Istana Peninggalan Masa Islam di Kesultanan Cirebon dalam Konteks Kesinambungan Budaya", dalam Cirebon sebagai Bandar Jalur Sutera Kumpulan Makalah Diskusi Ilmiah, Jakarta : Proyek IDSN.

Johan, Irma M., 1996.

"Penelitian Sejarah Kebudayaan

Cirebon dan Sekitarnya Antara Abad XV - XIX : Tinjauan Bibliografi", dalam Cirebon Sebagai Bandar Jalur Sutera Kumpulan Makalah Diskusi Ilmiah, Jakarta : Proyek IDSN.
Juhdi, Susanto (penyunting), 1996.

Cirebon Sebagai Bandar Jalur

Sutera Kumpulan Makalah

Diskusi Ilmiah, Jakarta : Proyek IDSN.

Kosoh S. dkk., 1995/1996.

Sejarah Daerah Jawa Barat, Jakarta : Proyek IDSN.

Lasmiyati, 1995.

"Sejarah Keraton Kasepuhan di

Kota Cirebon", dalam Laporan

Penelitian Edisi 8/XII/1995,

Bandung : Balai Kajian Sejarah dan Nilai Tradisional Bandung.

Masyhuri, 1989.

Ensiklopedi Nasional Indonesia Jilid IV dan VIII, Jakarta : PT Cipta Adi Pustaka.

Poesponegoro, Marwati Djoenoed dan Nugroho Notosusanto, 1990.

Sejarah Nasional Indonesia Jilid $I V$, Jakarta : Depdikbud - Balai Pustaka.

Salana, 1978

Sejarah Cirebon I (Stensilan).

Sudjana, T.D., 1996.

"Pelabuhan Cirebon Dahulu dan Sekarang", dalam Cirebon Sebagai Bandar Jalur Sutera Kumpulan Makalah Diskusi Ilmiah, Jakarta : Proyek IDSN

Sulendraningrat PS., 1984.

Babad Tanah Sunda, Babad Cirebon.

1987.

Sejarah Cirebon dan Silsilah Sunan Gunung Jati Maulana Syarif Hidayatullah, Cirebon : Asy-Syarqiyah. 
Sunardjo, RH. Unang, 1983.

Meninjau Sepintas Panggung Sejarah Pemerintahan Kerajaan
Cirebon 1479 - 1809, Bandung : Tarsito. 